\title{
9 \\ Kazakhstan: Civil Society and Natural Resource Policy in Kazakhstan
}

\section{Roman Vakulchuk and Indra Overland}

\section{Introduction}

In this chapter we discuss public debate on natural resource management in Kazakhstan and outline the roles of various players in shaping the debate. We find that civil society has had a limited role in the management of the petroleum sector, and public discussion of oil and gas issues has been driven mainly by the government and international organizations.

Kazakhstan possesses 3\% of global oil reserves, placing it among the world's top 15 countries in terms of oil reserves. There are 172 known oilfields in Kazakhstan, the largest ones being Karachaganak, Kashagan and Tengiz. More than 80 of the oilfields are under development (Cohen

R. Vakulchuk $(\bowtie)$

Norwegian Institute of International Affairs, Oslo, Norway

I. Overland

Head of the Energy Programme, Norwegian Institute of International Affairs, Oslo, Norway 
2015). Unlike petro-states such as Nigeria or Turkmenistan, Kazakhstan ended up largely privatizing its energy sector, and foreign investors were given a free hand in the 1990s. Seeking to deal with the economic crisis brought on by the collapse of the Soviet Union, the government offered the country's main oilfields to international oil companies, through production-sharing agreements (PSAs) that were attractive to foreign investors but opaque to the Kazakh public (Udartsev 2004; Kennedy and Nurmakov 2010; Ahmadov et al. 2012; Tsalik 2003).

However, after the year 2000 the government changed its policy towards international oil companies. The government toughened the regulatory regime, strengthened the role of national companies and revised the energy legislation (Hosman 2009). Some contracts were renegotiated, opening the way for greater government take. Several scholars have explained these changes with reference to the growing resource nationalism in Kazakhstan during that period (e.g. Kennedy and Nurmakov 2010; Sarsenbayev 2011).

The main issues in the evolving public debate on natural resource management in Kazakhstan have been the distribution of oil income between resource-rich and other regions, the establishment of the National Fund of the Republic of Kazakhstan (NFRK) in the year 2000 and Kazakhstan's membership in the Extractive Industries Transparency Initiative (EITI) since 2005. The first attempts to question lack of transparency in natural resource management date back to the early 2000s and were made not only by the general public but also by international NGOs operating in Kazakhstan (KIPR 2015). Moreover, government representatives stressed the need to improve transparency in order to show that the country met international standards (Kazpravda 2004). Later on, civil society continued the debate in a more concerted, albeit limited, manner. The next sections review the roles that the various types of civil society actors have and have not played in the Kazakh context.

\section{NGOs}

As Wilson and Van Alstine $(2014,40)$ note, civil society in Kazakhstan is weakly developed, with only a few 'truly independent organisations'. Given the lack of free civic culture during Soviet times, Kazakhstan in the 
1990s had little experience with NGOs. Instead it was international organizations that established and supported many NGOs during that period and became instrumental in the building of Kazakhstan's civil society (Diachenko 2007; Makhmutova and Akhmetova 2011; Overland 2005, 63). According to Luong and Weinthal (2010, 289), 'international NGOs have served as a conduit for raising awareness of the plight of local populations affected by negative externalities of oil and gas exploration and production' in resource-rich regions.

Since 2003, the international NGO Crude Accountability has been working with local people in the town of Berezovka in Kazakhstan, to raise general awareness of the environmental hazards related to the Karachaganak and Kashagan oilfields and demand compensation from the state (Crude Accountability 2003). The Aarhus Centre, supported by the Organization for Security and Co-operation in Europe (OSCE), has been present in Kazakhstan since 2001, also in oil-rich regions, working with the local authorities and the private sector on environmental issues. Eko-Mangistau, established in 2000, has been supported by various international donors.

Legislation aimed at regulating and supporting NGOs was adopted in the early 2000s. A law on non-commercial organizations was passed in 2001, and in 2002 the Concept of State Support for NGOs was adopted, setting out government support measures for the NGO sector. In 2004, several local NGOs formed the coalition 'Oil RevenuesUnder Public Oversight' to monitor Kazakhstan's EITI membership. The motivation for joining EITI in 2005 was to boost government credibility by increasing transparency in the natural resource sector. The creation of the NGO coalition was one of the first major signs of emerging interest from civil society actors as regards the petroleum sector.

In 2007, Kazakhstan was granted EITI candidate status. A successful example of civil society influence on the government was the issuing of a decree in 2006 obliging natural resource companies to meet EITI requirements as a necessary condition for further contracts (NRGI 2013). Wilson and Van Alstine $(2014,41)$ opine that, on the whole, 'public awareness has grown along with the depth of engagement of NGOs in the EITI process'. 
In 2009, the government applied for EITI-compliant status for the first time, but failed to obtain it due to objections from the NGO coalition. The NGOs regarded the progress made by the government (in particular, limited stakeholder representation) as insufficient for full membership, and this position was taken into account by the EITI Secretariat. In response, the government expanded the inclusion of stakeholders in the National Stakeholder Council (the multi-stakeholder management and oversight group set up for EITI) and invited more actors to join it (World Bank 2013). ${ }^{1}$ Ospanova et al. $(2013,17)$ note the important role played by the coalition in the debate on petroleum sector management in Kazakhstan:

[I]n discussions around EITI in Kazakhstan, proponents feel there should be more relevance to oil, gas and mining regions such as Atyrau, Aktau, Uralsk, Kyzylorda, Aktobe and Karaganda. This includes addressing issues such as how extractive industry-related funds are spent locally and how civil society, industry and government engage at the local level. Other important issues brought up repeatedly by the CSO [Civil Society Organization(s)] coalition and other stakeholders include: disaggregated reporting, transparency of social investments and wider participation in EITI of all extractive companies.

In 2013, Kazakhstan achieved EITI-compliant status, meaning that EITI recognized that the country had achieved progress in enhancing transparency. EITI reports on Kazakhstan include disclosure of social expenditure by companies and detail about the revenue channels that make up the national budget. Over the eight-year period of active cooperation among stakeholders under EITI, seven national reports disclosing revenues from the extraction of natural resources were released and made available to the public on the website of the National EITI Secretariat (EITI Kazakhstan 2016). The 2013 report included data from 170 companies - more than in any of the 35 other EITI-reporting countries (World Bank 2013).

However, the NGO coalition set up to engage with EITI in Kazakhstan proved unstable due to internal conflicts (EITI 2015). In 2013, after meeting the necessary EITI requirements and accomplishing its mission 
of securing EITI-compliant status, the coalition ceased to be an active player. This exemplifies a more general point: many $\mathrm{NGOs} \mathrm{in}$ Kazakhstan — with some exceptions, such as the NGO Eko-Mangistauare ad hoc initiatives created to solve specific problems. Moreover, linkages between the general population and NGOs are generally weak: 'citizens are often only interested in civil society's work at particular, sporadic moments' (Makhmutova and Akhmetova 2011, 49). Most local NGOs have short lifespans; however, some active individuals and experts from disbanded NGOs stay committed and join new initiatives.

Kazakh citizens generally lack basic knowledge of EITI's purpose and institutions. Because there is limited feedback from the public, the EITI process mostly involves specialized NGOs, rarely drawing in the broader population. This is similar to many other EITI member states (Cater 2013, 74-75). In 2013, Svetlana Ushakova, a representative of the NGO coalition, noted: 'There are benefits. Disclosed data allows the experts from society [eksperty ot obshestvennosti] to analyse them' (Better.kz 2013). However, Oksana Martynyuk (EITI Kazakhstan 2013) has argued that members of the public have little awareness of EITI and its mission. According to a local newspaper article reposted by the Committee of Geology and Subsoil Use under the Ministry for Investment and Development of Kazakhstan:

[D]espite increased transparency and the publication of EITI reports between 2005 and 2015, few Kazakhs know about these reports. Even if some do, they have little understanding of how to use the data in those reports and why they need them at all. (Ustinka.kz 2016)

Another significant transparency initiative in Kazakhstan also promoted by international organizations and NGOs is the Resource Governance Index (RGI), which ranks Kazakhstan 19 out of 58 resource-rich countries (NRGI 2013). The government provides only partial information on natural resource extraction and therefore scored no more than 58 out of 100 points. This is partly explained by the terms of contracts signed by the government and investors, which restrict the sharing of detailed information that might encourage active public participation. 
Thus, civil society in general has limited experience participating in public and critical discussion of natural resource issues. Most of the transparency and public scrutiny initiatives in Kazakhstan's petroleum sector have been initiated by international NGOs.

\section{Mass Media}

Kazakhstan's position in the World Press Freedom Index in 2016 was 160 out of 180 countries, down from 154 in 2012. This indicates not only that freedom of expression is restricted but also that the situation is not improving (RSF 2015; Overland 2012). Most Kazakh mass media have applauded government initiatives in the petroleum sector, such as contract renegotiation with foreign oil companies, the introduction of the concept of Kazakh content, the 2010 Law on Subsoil Use, the creation of the NFRK and joining EITI.

The opposition media have occasionally voiced the need for strengthening civil society control over natural resource use and for greater transparency, accountability and management of the petroleum sector. Oil revenue distribution and the role of NFRK have been important topics discussed in these media. Peter Svoik, an expert and representative of the opposition party Azat, noted at a roundtable organized by Radio Azattyq (2010) that the transparency of oil production and revenues is limited and that they are 'legally intransparent' given the nature of the PSAs signed in the 1990s (cited in Radio Azattyq 2010). Oraz Jandosov, Director of the RAKURS Center for Economic Analysis, mentioned that 'we gathered one million signatures in 2003 to make all the oil and gas contracts transparent and publicly accessible. So far we have not heard back [from the government]' (Jandosov cited in Radio Azattyq 2010). According to Galib Yefendiyev, Regional Coordinator of the Revenue Watch Institute, the lack of clarity on the calculation of the share of revenue to be returned to the oil-producing regions is the main cause of social tension in these parts of the country (cited in Forbes.kz 2014).

Our impression is that the local population tends to take a pessimistic view of political opposition, seeing opposition voices as undermining 
the country's stability. Similarly, Makhmutova and Akhmetova (2011, 49) argue that Kazakh citizens tend to take a sceptical view of civil society and NGOs. To understand the attitude of the Kazakh population, we must take into account the historical and geographical context: the painful unravelling of the Soviet industrial economy and the repeated revolutions and upheavals in other post-Soviet countries. Particularly salient has been the precedent set by neighbouring Kyrgyzstan, which is ethnically and linguistically closely related to Kazakhstan. Kyrgyzstan's two revolutions and one violent ethnic conflict during the post-Soviet period left the country poor and unstable and do not encourage emulation. Add to that the presence of conflict-ridden countries such as Afghanistan and Tajikistan in the neighbourhood, and the people of Kazakhstan have strong incentives for endorsing stability over other values. The two largest neighbours, China and Russia, set examples of how it is possible to achieve stability and economic growth with limited democracy, further reinforcing the impression that stability is more important than free speech (Overland et al. 2010, 93; Overland and Torjesen 2010, 136; Anker et al. 2010).

\section{Think-Tanks and Research Institutes}

Local think-tanks and research institutes in Kazakhstan have not influenced the public debate on a regular basis. There are two possible reasons for this. First, Kazakhstan lacks a tradition of drawing on the work of social scientists and experts to inform public debate. Second, in their reports, Kazakh researchers tend to provide mainly descriptive analysis of the petroleum industry, offering few insights on how governance of the sector could be improved. We should note, however, that their research is also hampered in the first place by lack of information from the government and oil companies operating in Kazakhstan. One example of this is the problems with data availability experienced by NRGI.

As there are not many Kazakh think-tanks, there is only limited independent expertise. Four main think-tanks review developments in the country's petroleum sector, but they do so only irregularly. The first one is 
the Institute of Political Solutions (IPR), which existed in 2009-2013 and was then transformed into the analytical group KIPR. It occasionally organizes roundtable discussions on natural resource management and conducts opinion polls. A major roundtable expert discussion was held in 2015 and assessed the efficiency and transparency of the National Fund (see KIPR 2015). While the main local experts took part in the event, representatives of state agencies stayed away in spite of lengthy negotiations with the organizers.

A second important think-tank is the Kazakhstan Investment Profitability Research Agency (AIRI). One of the main topics in its reports is the resource curse. The director of AIRI, Kainar Kozhumov, has regularly stressed the need to diversify the economy away from oil (Kozhumov 2011).

A third relevant think-tank is the Public Policy Research Center (PPRC), headed by Meruert Makhmutova, who is often interviewed by the media and acts as a partner in international research projects. The PPRC is viewed as a credible research institute, with a focus on extractive industries, revenue transparency and NFRK (see, e.g. Makhmutova 2006).

A fourth think-tank is the research centre Sange. This think-tank lists on its website all the studies it conducted between 1999 and 2014 (Sange 2017): of a total of 125 studies, only four dealt with natural resource management. Whereas the government is one of the main funders of most of Sange's studies and reports, these four studies were funded by international donors-exemplifying how contributions to the public debate in Kazakhstan have been driven largely by international donors.

With the partial exception of the analytical group KIPR, the contributions of local think-tanks and research centres to the debate are largely donor-driven and feed public debate only sporadically. However, experts representing these think-tanks often appear in the media to comment on various issues related to the petroleum sector.

In many ways, international research organizations have been more active contributors to the debate than have local think-tanks. For instance, the Soros Foundation and the International Institute for Environment and Development (IIED) have studied the structure of 
PSAs, governance and transparency in the oil and gas sector and actively collaborated with local researchers (see, e.g. Ahmadov et al. 2012; Ospanova et al. 2013; Ospanova and Cotula 2015). They have also held regular roundtable meetings and disseminated their findings (see, e.g. IIED 2012). The Soros Foundation in Kazakhstan has operated both as an NGO and a think-tank in Kazakhstan since 1995 and has organized research and capacity-building activities aimed at raising awareness about natural resource management (Wilson and Van Alstine 2014, 41).

These and other international NGOs have contributed to the public debate on natural resource management in Kazakhstan. While it is difficult to assess the real scope of their impact on the formation of public opinion, it is evident that they have provided important input for legislation and helped turn local think-tanks into emerging actors.

\section{Political Parties and Trade Unions}

One political party, Nur Otan, dominates the political agenda. It holds three quarters of the seats in the Parliament and mostly promotes official state policies on natural resource issues. Other parties hardly participate in the debate. In any case, the role of Parliament is limited. According to the Natural Resource Governance Institute, legislative oversight of petroleum sector management is limited, as 'the president maintains considerable power over the extractive sector' (NRGI 2013). Political parties are widely viewed as dysfunctional, and society remains convinced that they can hardly bring change (Isaacs 2011).

Also trade unions in Kazakhstan are weakly developed. Tripartite agreements are widespread, but real decision-making processes between the state, employers and trade unions take place elsewhere. State-civil society dialogues 'are often treated as a proforma instrument' by the state and carry little content (Makhmutova and Akhmetova 2011, 10). Since 1991, there have been serious labour conflicts in the following extractive companies: ArcelorMittal, Karazhanbasmunai, Kazakhmys, Kazchrome, KSP Steel, Petro Kazakhstan, Tengizchevroil and Uzenmunaigaz. The case of Zhanaozen stands out as one of the most critical in Kazakhstan's 
post-Soviet period. When the local authorities failed to solve a labour dispute, this ultimately led to bloodshed and the killing of 16 workers in December 2011. A key factor in the conflict was the weak interaction and poor coordination between central and local government, between state authorities and trade unions in the petroleum sector, and the excessive use of force on the part of the authorities (Human Rights Watch 2012; General Prosecutor 2012).

Official trade unions have generally proven unable to resolve labour conflicts in the petroleum sector. Workers have little trust in trade unions and their ability to protect workers' rights (Satpayev and Umbetaliyeva $2015,128)$. We must therefore conclude that the political parties and trade unions play only a minor role in the discourse on petroleum sector management in Kazakhstan.

\section{International Organizations and Foreign Investors}

The limited role of local civil society has been partly compensated for by Kazakhstan's exposure to international best practices through interaction with international organizations. ${ }^{2}$ The government has relied on reform strategies proposed by these international organizations: for instance, the structural economic reforms of the 1990s were elaborated mainly by hired senior economists from the World Bank and the IMF. In their reports, international organizations have criticized the government for overdependence on natural resources and limited success in diversifying the economy away from oil (ADB 2013; IMF 2010).

International organizations have promoted liberal economic reforms, the adoption of best international practices, improved transparency in natural resource management, green economy and inclusive growth. The Kazakh government has often been keen to show its commitment, hoping to meet expectations so as to ensure continued access to capital and convey a positive international image for the country. The example of EITI is illustrative. After Kazakhstan was awarded EITI-compliant 
status in 2013, the World Bank officially welcomed the country's new status and pledged to further support Kazakhstan's reforms (2013). ${ }^{3}$ Other examples of international influences on Kazakhstan include the setting up of the NFRK drawing on the Norwegian model and the adoption of e-government based on the success stories of Estonia, Singapore and other Asian and Western countries. The introduction of e-government enhanced transparency in official communication between society, business and the government, as assessed by representatives of foreign petroleum companies operating in Kazakhstan (Vakulchuk 2016, 1190).

Like international organizations, international oil companies have played an active role in shaping and influencing natural resource management, though in a less visible way (Ostrowski 2010, 149), especially in the early 1990s. Interestingly, societal expectations towards the state are deemed to be low in Kazakhstan, whereas expectations towards foreign investors are high, especially in the oil-rich parts of the country (Luong and Weinthal 2010). The strengthening of the local content regime in 2010 further reinforced these expectations.

In Kazakhstan, the main point of contact between the government and the big international oil companies is the Foreign Investors' Council (FIC) established in $1998 .{ }^{4}$ For the companies, FIC is an important platform for influencing oil and gas legislation. However, we have not found any indication that civil society representatives participate in FIC meetings. Moreover, the establishment of a main point of contact has been criticized as creating opportunities for corruption (Tsalik 2003, 138). Thus, the FIC may help to enhance communication between the government and international oil companies, but it contributes little to public transparency in Kazakhstan's petroleum sector and constitutes a missed opportunity for involving the broader public.

We see that international organizations have sometimes complemented, sometimes substituted for local civil society actors in Kazakhstan. Because local civil society has been passive, international organizations have in many cases initiated and advanced public debate on natural resource management (see also Fjaestad and Overland 2012). 


\section{NFRK}

As the National Fund of the Republic of Kazakhstan (NFRK) is one of the topics that have been discussed most widely in the debate on natural resource management in Kazakhstan, it merits a detailed presentation here. In its reform processes, Kazakhstan has been trying to learn from the successful experiences of other countries (Tsalik 2003; Vakulchuk 2014). Table 9.1 shows examples of countries that have served as role models for Kazakhstan in various areas. The NFRK was established to improve petroleum revenue management and stabilize fiscal policy by drawing on the experiences of other sovereign wealth funds, especially the Norwegian Government Pension Fund (ESMAP 2006).

According to the IMF $(2010,20)$, the purpose of the NFRK is to reduce the economic impact of volatile oil prices and serve as a vehicle for saving part of Kazakhstan's oil income for future generations'. It is regulated by the National Bank of Kazakhstan on behalf of the government, with ultimate decision-making power held by President Nazarbayev. All the Fund's capital is invested abroad. Direct taxes from the oil sector (except for taxes going to local budgets) are the main source of NFRK assets (IMF 2010). The Fund's assets grew from USD 0.96 billion in 2001 to almost USD 65.5 billion in 2015 (Sovereign Wealth Center 2017).

Table 9.1 Kazakh institutions and sources of inspiration

\begin{tabular}{ll}
\hline $\begin{array}{l}\text { Presidential system/Parliament } \\
\text { State and economic models }\end{array}$ & $\begin{array}{l}\text { France } \\
\text { China, Hong Kong, Russia, Singapore, South } \\
\text { Korea, Taiwan, Turkey, United Arab } \\
\text { Emirates }\end{array}$ \\
$\begin{array}{l}\text { EU model, Singapore } \\
\text { Tax system }\end{array}$ & $\begin{array}{l}\text { South Korea, the USA } \\
\text { Chile }\end{array}$ \\
Pension system & Japan, Norway, Singapore \\
Sovereign wealth fund & Finland, Malaysia, United Arab Emirates \\
Construction and infrastructure & Finland \\
Innovation policy & Arab countries, Germany \\
Banking and finance industry & Finland, Germany, South Korea, the USA \\
Education & Russia, the USA \\
Agriculture &
\end{tabular}

Source: Vakulchuk 2014, 181 
From the outset, the Fund has not been fully transparent (Tsalik 2003). According to $\operatorname{ESMAP}(2006,88)$ :

[T]he lack of full transparency for the fund prevents informed public discussion on its performance and use. The partial and occasional release of data on the size of the fund through the Kazakhstan News Bulletin and the summary of the audit and annual report give some information on its workings, but the lack of detail and regular publication is in sharp contrast to the situation for other oil funds.

A 2010 survey conducted by the Central Asian Fund for Democracy Development revealed that $63 \%$ of the population believed that the Fund's reserves were used inefficiently and 58\% felt that data accessibility was a major issue. Only $10 \%$ of those surveyed were satisfied with the information provided by state agencies on the Fund's operations (Satpayev and Umbetaliyeva 2015, 124). On the Linaburg-Maduell Transparency Index of sovereign wealth funds (SWFI 2012), NFRK is ranked low, scoring only two out of ten points. According to Erlan Smailov (KIPR 2015), who heads the think-tank KIPR, 'there is an information and responsibility deficit when it comes to the fund's activity and operations'. According to Bayan Shapagatova, a local consultant who worked for more than ten years at the National Bank of Kazakhstan:

By comparison, the Kuwait National Fund has five members in the Board of Directors and three of them represent the private sector. Six out of nine members of the Board at the South Korean sovereign wealth fund also represent the private sector. In our situation, the commission that controls the fund's management consists only of state sector representatives. There is a conflict of interests and no independent expertise. We need to include more representatives of the private sector in it. This should push for more transparency. (KIPR 2015)

Svetlana Ushakova, another participant in the expert discussion organized by KIPR (2015), pointed out that the current concept of the NFRK does not include civil society representatives. And yet, despite substantial transparency gaps, the fund remains an important instrument for the government to uphold stability in the country. For example, during the 
economic crisis of 2008, the government used NFRK assets to save those parts of the economy that were hardest hit: the financial sector and real estate market. This served to pre-empt potential social unrest and bolstered public support for government policy and the Fund (Kemme 2012; Inform.kz 2016).

\section{Conclusions}

The scope of the public debate and its impact on decision-making in natural resource management on Kazakhstan remains limited. It is shaped largely by a narrow circle of experts and NGOs, with most initiatives supported and promoted by international organizations. The contributors to policymaking on natural resources in Kazakhstan, ranked by their role in the public debate, are as follows: (1) the state, (2) international organizations, (3) foreign investors, (4) NGOs, (5) think-tanks and research institutes, (6) mass media and (7) political parties and trade unions.

Civil society has had little role in the management of natural resources in Kazakhstan. It has remained stunted, with scant experience in promoting its interests vis-à-vis the state. Public discussion of natural resource issues has been largely government-driven. Most government actions are tacitly accepted by society. The fact that Kazakhstan made a notable step forwards, from having a collapsed economy in the 1990s to becoming an emerging regional economic player with improved social and economic performance in the 2000s, helped legitimize the opacity of government policy on natural resource issues. As long as natural resource management seems effective in economic and social terms, it is supported by the broader public, which puts a premium on stability. On the other hand, as argued by Satpayev and Umbetaliyeva (2015), since 2010 the population has become increasingly willing to question existing natural resource governance arrangements.

Kazakhstan's exposure to international sources of influence, coupled with the activities of international organizations and donors, has served as a partial substitute for weak civil society. They have motivated the government to adopt best practices in natural resource management and 
have contributed greatly to the establishment of the semblance of an NGO sector. They have triggered some debate on critical issues of petroleum sector governance. Driven by the desire to boost its international reputation, the government has refrained from hindering international NGOs from entering and operating in the country.

The contrast between Kazakhstan and another Turkic, Central Asian country-Turkmenistan-is worth noting. Whereas both score low on international indices of democracy, free speech and corruption, Kazakhstan has managed to maintain significantly higher standards in its natural resource management. One important difference between the two countries and their natural resource management is that Kazakhstan has shown far greater openness to the influence of other countries and international organizations.

\section{Notes}

1. More government representatives, MPs, oil and mining companies, including Kazenergy (the association for oil and gas producers and service providers for the energy sector in Kazakhstan) and the Association of Mining Producers, were invited, as well as NGOs.

2. International organizations active in Kazakhstan include the Asian Development Bank (ADB), the European Bank for Reconstruction and Development (EBRD), the Extractive Industries Transparency Initiative (EITI), the International Finance Corporation (IFC), the International Institute for Environment and Development (IIED), the International Monetary Fund (IMF), the Kazakhstan Revenue Watch (KRW) programme organized by the Soros Foundation-Kazakhstan, the Organisation for Economic Co-operation and Development (OECD), the Organization for Security and Co-operation in Europe (OSCE), the World Bank, numerous UN agencies, and others.

3. As Sebnem Akkaya, World Bank Country Manager for Kazakhstan, has noted: 'Our interest in EITI is part of our overall governance strategy, and in many countries, including Kazakhstan, the Bank works with governments on the EITI agenda as part of broader Bank-supported programs on extractive industries reform, natural resource management, and good governance/anti-corruption' (cited in World Bank 2013). 
4. Only a few developing petro-states have managed to establish petroleum associations that actually do lobbying - and Kazakhstan is one of them (Luong and Weinthal 2010, 211; Vakulchuk 2014, 195).

\section{References}

ADB. 2013. Policies for Industrial and Service Diversification in Asia in the 21st Century: Report to the Government of Kazakhstan. Manila: ADB.

Ahmadov, Ingilab, Anton Artemyev, Kenan Aslanly, Ibragim Rzaev, and Ilkham Shaban. 2012. How to Scrutinize a Production Sharing Agreement. London: IIED.

Anker, Morten, Pavel Baev, Bjørn Brunstad, Indra Overland, and Stina Torjesen. 2010. The Caspian Sea Region Towards 2025: Caspia Inc., National Giants or Trade and Transit? Delft: Eburon.

Better.kz. 2013. Kazakhstan idet k prozrachnosti. http://better.kz/ ru/20130719/russkij-kazaxstan-idet-k-prozrachnosti. Accessed on 22 February 2017.

Cater, Charles. 2013. Corruption and Global Governance. In Governing the World? Cases in Global Governance, ed. Sophie Harman and David Williams, 62-78. London: Routledge.

Cohen, Ariel. 2015. Beyond Oil and Gas: Kazakhstan Bets Its Future on Reform. Journal of Energy Security. http://www.ensec.org/index.php?option=com_con tent\&view=article\&id=578: beyond-oil-and-gas-kazakhstan-bets-its-futureon-reform\&catid=146: cenrg\&Itemid=439. Accessed on 24 February 2017.

Crude Accountability. 2003. Kazakhstan. http://crudeaccountability.org/ kazakhstan/. Accessed on 24 February 2017.

Diachenko, Sergey. 2007. The Government and NGOs in Kazakhstan: Strategy, Forms, and Mechanisms of Cooperation. Central Asia and the Caucasus 1 (43): 44-56.

EITI. 2015. The EITI Requirements. https://eiti.org/eiti/requirements. Accessed on 19 December 2016.

EITI Kazakhstan. 2016. National EITI Reports. http://eiti.geology.gov.kz/en/ national-reports. Accessed on 27 February 2017.

ESMAP. 2006. Experiences with Oil Funds: Institutional and Financial Aspects. World Bank. Report 321/06. https://www.esmap.org/sites/esmap.org/files/ FR321-06_GBL_Experiences_with_Oil_Funds.pdf. Accessed on 1 April 2017. 
Fjaestad, Kristin, and Indra Overland. 2012. Energy Elites in Central Asia: Kazakhstan, Turkmenistan and Uzbekistan. RussCasp Working Paper. Oslo: FNI.

General Prosecutor. 2012. Statement on the Investigation of Mass Disturbances in Zhanaozen. http://kazembassy.no/index.php?mact=News,cntnt01,print,0 $\&$ cntnt 01 articleid $=542 \&$ cntnt 01 showtemplate $=$ false $\&$ cntnt 01 retur nid=131. Accessed on 16 April 2013.

Hosman, Laura. 2009. Dynamic Bargaining and the Prospects for Learning in the Petroleum Industry: The Case of Kazakhstan. Perspectives on Global Development and Technology 8: 1-25.

Human Rights Watch. 2012. Striking Oil, Striking Workers: Violations of Labour Rights in Kazakhstan's Oil Sector. http://www.hrw.org/sites/default/ files/reports/kazakhstan0912ForUpload_0.pdf. Accessed on 18 December 2016.

IIED. 2012. EITI and Sustainable Development: Perspectives from Aktau, Kazakhstan. Workshop Report. http://pubs.iied.org/pdfs/G03490.pdf. Accessed on 28 February 2017.

IMF. 2010. Republic of Kazakhstan: Selected Issues. IMF Country Report No. 10/237. http://www.imf.org/external/pubs/ft/scr/2010/cr10237.pdf. Accessed on 20 December 2016.

Inform.kz. 2016. Nezavisimost: Khronika sobytiy. http://www.inform.kz:8080/ rus/article/2970702 Accessed on 20 December 2016.

Isaacs, Rico. 2011. Party System Formation in Kazakbstan: Between Formal and Informal Politics. London: Routledge.

Kazpravda. 2004. Natsionalny fond: Kopit ili tratit.... Kazahstanskaya pravda. http://www.nomad.su/?a=2-200409130023. Accessed on 28 February 2017.

Kemme, David. 2012. Sovereign Wealth Fund Issues and The National Fund(s) of Kazakhstan. William Davidson Institute Working Paper No. 1036. https:// deepblue.lib.umich.edu/bitstream/handle/2027.42/133053/wp1036. pdf?sequence=1\&isAllowed=y. Accessed on 21 December 2016 .

Kennedy, Ryan, and Adilzhan Nurmakov. 2010. Resource Nationalism Trends in Kazakhstan, 2004-2009. RUSSCASP Working Paper. http://citeseerx.ist. psu.edu/viewdoc/download;jsessionid=DE73912BC4F36715D742970BC6 360C74?doi=10.1.1.620.4517\&rep=rep1\&type=pdf. Accessed on 1 April 2017.

KIPR. 2015. Effektivnost ispolzovaniya sredstv Natsfonda RK. www.agkipr.kz/ archives/644. Accessed on 28 February 2017. 
Kozhumov, Kainar. 2011. Iz-za syrevoy napravlennosti v ekonomike Kazakhstana Nablyudaetsya opredelennyy disbalans. http://mining.kz/arkhiv-novostej/ arkhiv-novostej/item/12989-. Accessed on 28 February 2017.

Luong, Pauline, and Erika Weinthal. 2010. Oil Is Not a Curse: Ownership Structure and Institutions in Post-Soviet Successor States. Cambridge: Cambridge University Press.

Makhmutova, Meruert. 2006. Upravleniye neftyanymi dokhodami: Kontseptsiya Natsionalnogo fonda. Almaty: Soros Foundation-Kazakhstan and Kazakhstan Revenue Watch.

Makhmutova, Meruert, and Aitzhan Akhmetova. 2011. Civil Society Index in Kazakhstan. Almaty: Public Policy Research Center.

Martynuk, Oksana. 2013. Oksana Martynyuk: Neprozrachnye neftedollary. http://eiti.geology.gov.kz/kz/about-us/publikatsii-v-smi/107-neprozrachnyeneftedollary. Accessed on 27 February 2017.

NRGI. 2013. Kazakhstan's Performance on the Revenue Governance Index. http://www.resourcegovernance.org/our-work/country/kazakhstan. Accessed on 20 December 2016.

Ospanova, Saule, Ingilab Ahmadov, and Emma Wilson. 2013. EITI and Sustainable Development: Lessons and New Challenges for the Caspian Region. London: IIED.

Ospanova, Saule, and Lorenzo Cotula. 2015. Transparency in Extractive Industry Legislation: Recommendations for Kazakbstan's Code on Subsurface Use. London: IIED.

Ostrowski, Wojciech. 2010. Politics and Oil in Kazakhstan. London: Routledge. Overland, Indra. 2005. Multilateral Organizations in the Caucasus and Central Asia. Central Eurasian Studies Review 4 (1): 63-64. - 2012. Slippery Slopes: Pitfalls for the Rulers of Resource-Rich States. In Challenges of the Caspian Resource Boom: Domestic Elites and Policy-Making, ed. Andreas Heinrich and Heiko Pleines, 35-45. Houndmills: Palgrave Macmillan.

Overland, Indra, and Stina Torjesen. 2010. Just Good Friends: Kazakhstan's and Turkmenistan's Energy Relations with Russia. In Caspian Energy Politics: Azerbaijan, Kazakbstan and Turkmenistan, ed. Indra Overland, Heidi Kjaernet, and Andrea Kendall-Taylor, 136-149. London: Routledge.

Overland, Indra, Stina Torjesen, and Heidi Kjaernet. 2010. China and Russia: Partners or Firewalls for the Caspian Petro-States? In Caspian Energy Politics: Azerbaijan, Kazakhstan and Turkmenistan, ed. Indra Overland, Heidi Kjaernet, and Andrea Kendall-Taylor, 93-100. London: Routledge. 
Radio Azattyq. 2010. Pochemu v Kazakhstan neprozrachny neftyanye dokhody? http://rus.azattyq.org/content/kazakhstan_oil_export_gain/2220691.html. Accessed on 19 December 2016.

RSF. 2015. Eastern Europe. Reporters Without Borders. https://rsf.org/ index2014/en-eastern-europe.php. Accessed on 20 December 2016.

Sange. 2017. Proyekty i khronologiya. http://www.sange.kz/index.php/proekty/. Accessed on 23 February 2017.

Sarsenbayev, Kuanysh. 2011. Kazakhstan Petroleum Industry 2008-2010: Trends of Resource Nationalism Policy? Journal of World Energy Law and Business 4 (4): 369-379.

Satpayev, Dossym, and Tolganay Umbetaliyeva. 2015. The Protests in Zhanaozen and the Kazakh Oil Sector: Conflicting Interests in a Rentier State. Journal of Eurasian Studies 6: 122-129.

Sovereign Wealth Center. 2017. National Fund of the Republic of Kazakhstan. http://www.sovereignwealthcenter.com/fund/46/National-Fund-of-theRepublic-of-Kazakhstan.html. Accessed on 23 February 2017.

SWFI. 2012. Linaburg-Maduell Transparency Index of Sovereign Wealth Funds. http://www.swfinstitute.org/statistics-research/linaburg-maduell-transparency-index/. Accessed on 25 February 2017.

Trubacheva, Tatyana. 2014. Bolshaya neftyanaya tayna Kazakhstana. Forbes.kz. https://forbes.kz/process/expertise/bolshaya_neftyanaya_tayna_kazahstana. Accessed on 25 February 2017.

Tsalik, Svetlana. 2003. Caspian Oil Windfalls: Who Will Benefit? New York: Caspian Revenue Watch.

Udartsev, Andrey. 2004. Improving the Law Relating to Production Sharing Contracts in Kazakhstan. In Oil and Gas Law in Kazakhstan: National and International Perspectives, ed. I. Bantekas, J. Paterson, and M. Suleimenov, 189-198. London: Kluwer Law International.

Ustinka.kz. 2016. V VKO pri podderzhke OBSE zapuskayut proekt dlya resheniya problem ecologii. http://geology.gov.kz/ru/novosti-ipdo/1149-v-vko-pri-podderzhke-obse-zapuskayut-proekt-dlya-resheniya-problem-ekologii-httpsustinka-kz-kazakhstan-society-v-vko-pri-podderzhke-obse-zapuskayut-proektdlya-resheniya-problem-ekologii-hcq-o3j15op. Accessed on 20 December 2016. Vakulchuk, Roman. 2014. Kazakhstan's Emerging Economy: Between State and Market. Frankfurt am Main: Peter Lang Press. . 2016. Public Administration Reform and Its Implications for Foreign Petroleum Companies in Kazakhstan. International Journal of Public Administration 39 (14): 1180-1194. 
Wilson, Emma, and James Van Alstine. 2014. Localising Transparency: Exploring EITI's Contribution to Sustainable Development. London: IIED.

World Bank. 2013. World Bank Welcomes Kazakhstan's EITI Compliance Status. http://www.worldbank.org/en/news/press-release/2013/11/01/worldbank-welcomes-kazakhstans-eiti-compliance-status. Accessed on 20 December 2017.

Open Access This chapter is licensed under the terms of the Creative Commons Attribution 4.0 International License (http://creativecommons.org/ licenses/by/4.0/), which permits use, sharing, adaptation, distribution and reproduction in any medium or format, as long as you give appropriate credit to the original author(s) and the source, provide a link to the Creative Commons license and indicate if changes were made.

The images or other third party material in this chapter are included in the chapter's Creative Commons license, unless indicated otherwise in a credit line to the material. If material is not included in the chapter's Creative Commons license and your intended use is not permitted by statutory regulation or exceeds the permitted use, you will need to obtain permission directly from the copyright holder.

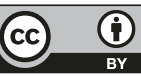

